\title{
A Critical Discourse Analysis of Short Story "Property of Woman" by Sara Suleri
}

\author{
Muhammad Imran Shah Rameen Hafeez \\ Department of Applied Linguistics, GC Uniersity Faisalabad Pakistan
}

\begin{abstract}
Postcolonial literature, by definition, is deeply concerned with the histories, normally with retelling or reassessing the way in colonial/ postcolonial histories have been presented in colonial/ western accounts (Ramone, J. 2013). Critical discourse analysis (CDA) as a tool used to analyse the spoken and written texts to expose the unrevealed ideologies. The purpose of the research is how the author has controlled the mind of people through the writing in short story "property of woman". The objective of the research is to highlight that what kind of lexicons (discourse markers, modifiers) are being used to control the minds of readers. The researcher has manually collected all kinds of lexicons (discourse markers and modifiers) from the story. This present study answers two questions: 1) What kind of discourse markers and modifiers are used by Sara Suleri to control the minds of readers? 2) How these discourse markers and modifiers are helping to clarify the main theme of the story "property of woman"? For the analysis of data, Van Dijk's Socio-cognitive model (2006) based on ideology and discourse, has been applied to explain the mind control. The result of the study is that the author has extensively used the lexicons which control the minds of her readers and engaged them in story. The conclusion of the study is that the theme of the story is sociological and ethnographic example of postcolonial literature which analyses female experience in social and political circumstances.
\end{abstract}

Keywords: postcolonial, literature, discourse markers, modifiers, nostalgia

DOI: $10.7176 /$ JLLL/64-04

Publication date: January $31^{\text {st }} 2020$

\section{Introduction}

Sara Suleri is a remarkable postcolonial literary figure (DAWN August 2008). She shows us the wonder and anguish of the childhood and surrounds us with the bold colours and sundry sounds of a volatile postcolonial Pakistan (Natasha Bronn 2003). Postcolonial literature, by definition, is the deeply concerned with histories, normally with retelling or reassessing the way in colonial or postcolonial history has been presented in colonial or western accounts. Postcolonial writing is sympathetic to the condition of those subjected to colonial control rather than to colonialists (Ramone, J. 2013). Suleri is describing her recollection regarding Lahore and cicadas and arrival of monsoons. She has described a character named Halima who had nostalgia about Pathar Nadi, who is the implied and ambiguous character of her story around whom the whole story is revolved. Sara has excellently maintained the theme of unity and coherence while composing the story. Being a Pakistani writer, she has a command in English language as her writing is enriched in excessive use of flowery words making the story complex and worthy.

Purpose:

The purpose of the study is to describe that how writers controls the reader's mind through their writings.

Objectives:

The objective of the research is to know that what kind of selected lexicons and intensifiers are used by Pakistani writers to control the minds of readers?

Research questions:

1) What kind of discourse markers and modifiers are used by Sara Suleri to control the minds of readers?

2) How these discourse markers and modifiers are helping to clarify the main theme of the story "property of woman"?

\section{Literature Review}

There has been much recent interest in conjunctions between biography and autobiography like memoir, history, and testimony, and postcolonial context. Though some of the key texts are general - including Moore-Gilbert's Postcolonial life-writing (2009), Gillian Whitlock's soft weapons (2007). Gloria Anzaldua's Borderlands, which is reviewed by many to be a theory of writing and identity. Similarly, Kingston's The Woman Warrior is often read as a literary fiction having a depiction as a memoir. Ramone, J (2013).

Mohsin Hamid's The Reluctant Fundamentalist (2007) is a fictional autobiography about a protagonist Changez, who narrated his memoir in America, and described the political and cultural difference of both Western society and Eastern society (An analysis of Mohsin Hamid's The Reluctant Fundamentalist by Abdul Baseer and Sofia Dildar Alvi, 8 August 2011). Abdul Baseer and Alvi S.D. (2011) has done a narratological analysis by following the model of Bremond, Genette, Abbott and Reman-Kenan. 
Colonized were the subaltern of colonial era and postcolonial societies have created their own subaltern. Women being disempowered in every society became the subaltern of postcolonial societies (Abroo Nazar 2016). As Spivak has said, "Between patriarchy and imperialism, subject constitution and object formation, the figure of the woman disappears... there is no place from where a sexed subaltern can speak' (Spivak, 1998). Muhammad Hanif has tried to capture the life of a postcolonial subaltern in his novel Our Lady of Alice Bhatti (2011) and declared her marginalization. Alice Bhatti is a subaltern of a postcolonial society. Nayar (2008) describes the postcolonial sub-alternation as, "if the native was the subaltern in the colonial era, postcolonialism created in its own subaltern, 'women, lower castes' and classes, ethnic minority rapidly became the others within the postcolonial nation state".

\section{Research methodology}

Data collection:

For this study, the researcher has collected the data from a short story "Property of Woman" in hard form from a book and typed it manually to extract the discourse markers and modifiers, which describes the power and mind control.

Research instrument:

The researcher has used the model proposed by Van Dijk "Socio-cognitive model" (2006) to describe the discourse and ideologies used by Sara Suleri that how power is manifested and produced in order to control the minds of readers.

Analysis:

The researcher has collected the discourse markers and modifiers from the short story "property of woman" composed by Sara Suleri, manually in a Microsoft Excel file. To discuss the power and mind control, the researcher has devised first the lists of all the lexicons and tried to explain the critical discourse analysis of the short story by throwing light upon the main themes.

Critical discourse analysis by using Van Dijk's model.

Access: The short story appears to be composed by a renowned Pakistani writer Sara Suleri with the interest in social and political circumstances, so, she has the exclusive access to the people of world. This fact makes her contribution in developing discourse and gets an access to share her thoughts and beliefs to all classes of society without discrimination.

Genre: The genre is a short story which in different writers' opinions is, "a short story must have a single mood and every sentence must build towards it" (Edgar Allan Poe, 2013). The text type is declarative in nature and is usually written to describe the nostalgia, culture and social circumstances of Lahore, Pakistan.

Communicative acts and social meanings: The short story is developing a discourse among it's readers and discussing the character of female in society. As the author herself is female and is a part of the story, thus she is using a postcolonial approach to describe the Pakistan condition after partition of 1947 and character's affiliation with her memoir.

Participant position and roles: As already mentioned the short story is written by the author with the interest in social and political circumstances and apparently having a significant authority in society as a writer. A remarkable character named Halima and her nostalgia about her past regarding another character mentioned in a story - Pathar Nadi - the ambiguous character.

Speech Act: The speech acts performed by the author and the main character Halima are mostly declarative and expressive, as they are depicting the memoir and their belongings to society. The discourse markers and modifiers used by the author and character are rich in number which results not only in describing the ideology and main theme of story but in grabbing the interest of readers also.

Macro-Semantics: Topics: the topic or title of the short story is "property of woman", wisely used by Sara Suleri. As she is a feminist and postcolonial writer, she prodigiously chooses the title and endeavours to describe the characteristics of female through her writing. She herself is a character in her story recalling her memoir as auto diegetic narrator. The researcher has intentionally used the discourse markers and modifiers as a linguistic feature to discuss the property of women that females use more discourse markers and modifiers (lexicons) in their speech.

Superstructures: Text schemata: The superstructures are being organized by conventional schemata which explains how part of text arranged into the whole. A story is a discourse which expresses a macrostructure which is organized by a narrative schema (Oley Nay di, 2011). The short story holds the cognitive and emotional function that clearly represents the superstructure. The author has marvellously organized the text and paragraph themes about her nostalgia and character Halima's nostalgia, and made the reader engage in story by describing the social and cultural glimpses of Pakistan, Pakistani troops, cicadas, monsoon, and characters (Halima and Pathar Nadi).

Local meaning and coherence:

a) Level of specificity and degree of completeness: the author has extensively used the pronoun "my" to 
explain certain things with personal association, for example "Oh my golden Kasur".

b) Perspective: the perspective of the Sara Suleri writing is autobiographical in the story "property of woman" in which she describes her memoir regarding Pakistan, her father's home town Lahore.

c) Implicitness: Sara Suleri has used presuppositions regarding the music or songs - another great asset of Pakistani Lollywood industry and specific affiliation with Pakistani troops to encourage them for the battle of 1965. Another presupposition is about the most ambiguous character Pathar Nadi and his arrival after seventeen years and Halima's intimacies with him.

Style: variation of syntax, lexicon and sound:

The word choice by author is not as such simple, it is complex, as the author is competitive enough in composing the story. the use of pronouns is common to describe personal association in story in order to make the readers engage in story by controlling their minds.

For instance:

"Do I have to see that horse in your room every day?"

"she would return to my room to squat. that I recognized as mine."

"I told my purchase."

"For my knowledge of him comes into pieces."

"Yet which of us was audience."

"Oh my golden town Lahore!"

The syntactic pattern of text is mostly compound complex and narrative is fabricated throughout the story. It seems to be a language of conversation as it is autobiography and involves the author's personal affiliation with the character Halima and Lahore, Pakistan.

The start of the topic is with the discussion of the setting: weather of Lahore, cicada's, and monsoon arrival, thus laying the foundation of main theme about the story "property of woman" and infusing the element of power or control used by the author to control the minds of readers via fabricated text.

\section{Result}

The lexicons and intensifiers used by Pakistani writer Sara Suleri have remarkably given a profound impact on readers by controlling their mind. As for as the purpose of writing a story or novel in a diction is concerned, the major concern is to control the minds of readers and making them engage in the story. The intensifiers and lexicons used by the author are rich in number, giving the story theme a sublime view. As a feminist, the author is master enough to explain the title through the story "the property of woman". Hence, the result of the study is that the lexicons and intensifiers like several adjectives and pronouns "we, mine, your, you, me etc." used by Pakistani writer Sara Suleri in her short story "property of woman" had a profound impact on the readers' perception which controlled their minds.

\section{Conclusion}

The purpose of writing a story in a specific diction is to aware the readers from the ethnic and social circumstances of his/her society and to trace their thoughts and imaginations in story. it is the foremost duty of a writer to raise a particular issue by throwing the light on it. As Sara Suleri, a feminist writer, portrays the female position in a Pakistani society, Halima, her emotions, her nostalgia, her social experience in the short story "property of woman". To conclude, the researcher has tried to explain that being a postcolonial writer, the author has splendidly described that the theme of story is sociological and ethnographic example related to postcolonial literature, which explained the situation and plot evenly, which analyses the female experience in social and political circumstances.

\section{References}

Anzaldúa, G. (1987). Borderlands: la frontera (Vol. 3). San Francisco: Aunt Lute.

Whitlock, G. (2010). Soft weapons: Autobiography in transit. University of Chicago Press.

Moore-Gilbert, B. (2009). Postcolonial life-writing: culture, politics, and self-representation. Routledge. http://www.languageinindia.com/aug2011/reluctantfundamentalistfinalpaid.pdf

Alvi, S. D., \& Phil, M. LANGUAGE IN INDIA.

Ramone, J. (2013). An Intimate Disconnection: Sara Suleri and the 'great machine at the heart of things: history'. Life Writing, 10(1), 61-76.

Van Dijk, T. A. (2006). Ideology and discourse analysis. Journal of political ideologies, 11(2), 115-140. 
Appendix:

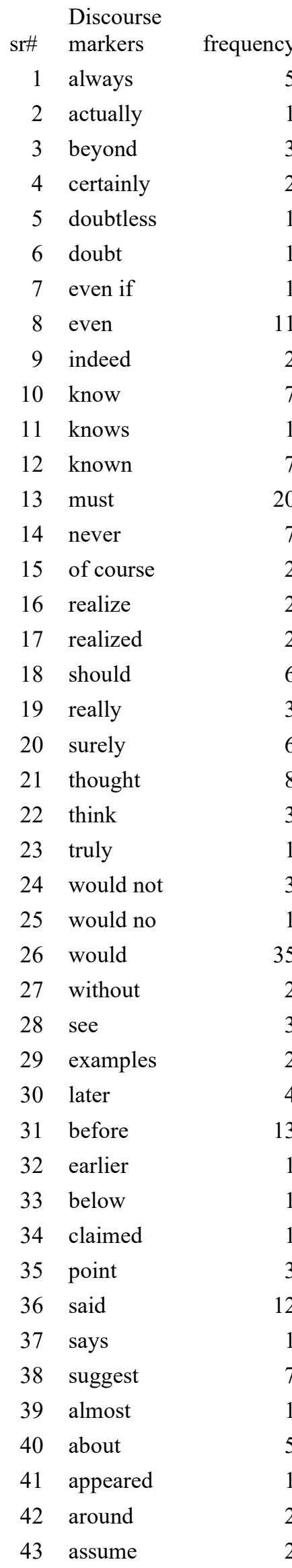




44 could not 3

45 could 37

46 feel 3

47 feels 1

48 from this 1

49 from 15

50 felt 5

51 frequently 2

52 guess 1

53 in our 1

54 indicate 2

55 largely 1

56 may 2

57 might 1

58 mostly 1

59 not 47

60 often 3

61 understood 1

62 possibly 2

63 probably 1

64 possible 2

65 perhaps 9

66 quite 5

67 should 8

68 seems 1

69 somewhat 2

70 suggest 6

71 suggested 1

$72 ! 3$

73 astonishing 2

74 curious 1

75 curiously 1

76 desire 2

77 fortunate 2

78 have to 2

79 interest 1

80 interested 1

81 must 20

82 understand 1

83 unfortunate 1

84 wished 4

85 intention 1

86 purpose 1

87 for the 11

88 moment 3 


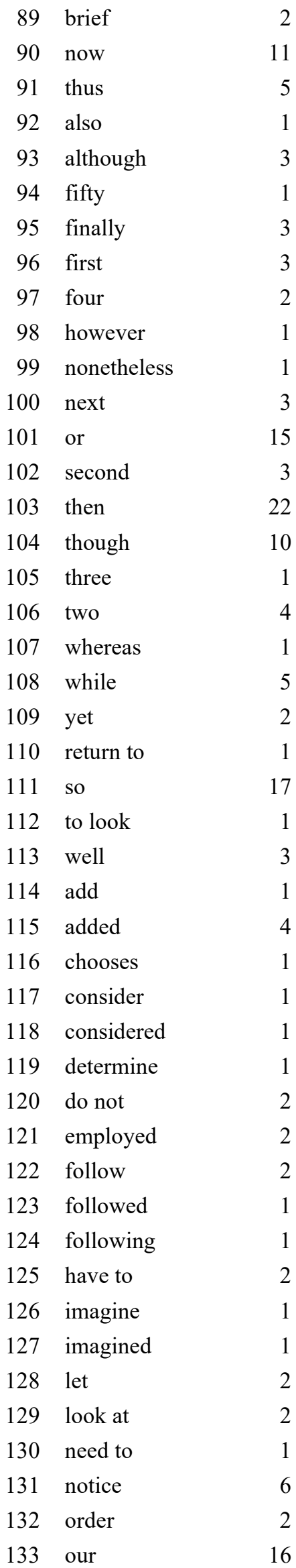




$\begin{array}{llr}134 & \text { pay } & 1 \\ 135 & \text { prepared } & 3 \\ 136 & \text { recall } & 1 \\ 137 & \text { referred } & 2 \\ 138 & \text { see } & 3 \\ 139 & \text { set } & 1 \\ 140 & \text { we } & 29 \\ 141 & \text { us } & 14 \\ 142 & \text { your } & 5 \\ 143 & \text { your } & 31 \\ 144 & \text { my } & 22 \\ 145 & \text { mine } & 2 \\ 146 & \text { me } & 22\end{array}$

